\title{
The Impact of a Training Program for Tactical Performance on the Results of Matches for Table Tennis Juniors
}

\section{"Dr. Shawkat Gaber Radwan}

\section{Abstract}

The research aims to design a training program for the tactical preparation to develop the tactical performance for table tennis juniors in the age groups of 12 - 15 years and know the effect of this program on the results of the matches. The researcher used the experimental method by using two groups, one is the experimental group and the other is the control group each of them consists 8 players from table tennis juniors in Ismailia city. The important findings, which were the researcher reached to, that the differences in the results of matches between the members of the control group and experimental group in the post-test was significant in favor of the experimental group. Which indicates that the proposed program has a positive impact on the development of the tactical preparation for table tennis juniors in the age group of 12 - 15 years.

Key words: table tennis - tactical preparation - tactical performance tactical thinking - matches results.

\section{$>$ Introduction:}

The process of learning and mastering the match strategy is one of the most difficult table tennis skills for the juniors, as this skill requires the player ability to focus to discover his opponent strengths and weaknesses. In addition to this skill requires a great deal of experience to realize what strategies work against various styles. These things may be difficult for the junior stage, especially if there was a shortage in the level of their performance for some strokes. (11:144)

Indicates (Peter Simpson 1981) that the main objective of tactical preparation in table tennis is owning the player both of attack and defense plans with a high level, and to have a flexibility that allows him to move from attack position to defense position and vice versa, therefore adaptation with changing

- Theories and Applications Athletics and Racket Games Department, Faculty of Physical Education, Port Said University, Assiut Journal For Sport Science Arts 
situations during the matches. $(9: 46)$

Defines

(Martin Skloroz

1980) the tactical performance in table tennis that it is an ability enabling the player to exploit his physical, technical and mental potential in a manner enabling him to perform the matches efficiently and effectively, as each of (Donald Parker \& David Hewitt 1993) define it that it is an ability enabling the player to use his own potential in the game with a maximum efficiency. (8:73), (5:70)

The tactical performance in table tennis is founded on some abilities such as:

- Knowledge abilities: represented in analyzing the points of strengths and weaknesses of opponent, and work to exploit the weaknesses and avoid the strengths.

- Technical abilities: represented in analyzing the strokes which performed by the opponent with regard to the type of ball rotation and its direction and speed and its arc of flight.

- Mental abilities: represented in the ability of player to persevere, stamina, focus attention, reaction speed and decisiveness in taking the right decisions and etc., $(2: 65,66)$

This, both of (Radivoj

Hudetz 2004) and (Wohlgefahrt Karlheinz 2004) are agreed that the primary means of tactical performance table tennis represents in four points:

1. The speed of ball.

2. The spin of ball.

3. Direction of the ball.

4. Arc of the ball flight. (10 : 15 - 28), (13: 161)

And see all of (Cheng Wu \& Prince Su 2010) that the essential points upon which the training on the tactical performance are:

1. Development the ability of the player to win the matches through tactical thinking.

2. Development the tactical performance for the player through training on:

- Tactical performance, which depends on both of the landing point and trajectory of the ball.

- Tactical performance, which depends on the rhythm of play during the match.

- Tactical performance, which depends on the different situations during the match. 
- Tactical performance, which depends on the opponent's style of play and his selection of quality of the strokes which he use.

- Tactical performance, which depends on the weaknesses of the opponent.

3. Development control in both timing of the play and emotional conditioning during the changing situations during the matches. (12:192)

Through the experience of researcher in the field of table tennis found that the most of table tennis trainers in Egypt satisfied with performing matches between the players in the custom part or the tactical preparation in the training unit, and they do not give the drills of tactical performance for the players. Which prompted the researcher to carry out this study, which aims to design a training program for tactical performance to develop the tactical performance for table tennis juniors in the age group of 12 to 15 years old, and recognize the impact of this program on the results of matches for this age group.

- Objectives:

1. Designing a training program of tactical performance for table tennis juniors $12-15$ years.

2. Identify the impact of this program on the results of matches for table tennis juniors.

\section{Procedures:}

\section{- Method:}

The researcher used the experimental method by using the pre- and post measurements and using two groups, one is an experimental group and the other is a control group each of them consists 8 players.

\section{- Participants:}

The sample was selected by intentional way, reaching 16 players from table tennis juniors in the age group of $12-$ 15 years in Ismailia region. The sample has been divided equally into two groups one of them is an experimental group and the other is a control group.

- The harmonies and equivalence between the members of study sample:

The harmonies and equivalence between the members of the study sample were conducted at the following variables:
1. Age.
2. Training age.
3. Height.
4. Weight. 
5. Some of physical variables (maximum strength, muscular endurance, power, speed, agility).

6. Some of skill variables (services, basic strokes, lop strokes).

Table (1) shows the characterization of the study sample in variables of age, training age, height and weight. Table (2) shows the harmonies of the study sample in some of physical and skill variables. While table (3) shows the equivalent between the two groups of study in some of physical and skill variables.

Table (1)

The characterization of the study sample

\begin{tabular}{|c|c|c|c|c|c|}
\hline $\begin{array}{l}\text { Statistical } \\
\text { analyses } \\
\text { Variables }\end{array}$ & $\begin{array}{c}\text { Measurements } \\
\text { unit }\end{array}$ & Mean & Median & \begin{tabular}{|l|} 
Standard \\
deviation
\end{tabular} & Skewness \\
\hline Age. & Year & 13.03 & 13.08 & 0.93 & -0.04 \\
\hline Training age. & Year & 5.86 & 6.07 & 0.98 & -0.58 \\
\hline Height. & $\mathrm{Cm}$ & 1.57 & 1.59 & 0.06 & -0.45 \\
\hline Weight. & $\mathrm{Kg}$ & 59.31 & 60.00 & 3.77 & -0.28 \\
\hline \multicolumn{3}{|c|}{$\begin{array}{l}\text { It is clear from table (1) } \\
\text { that all of the skewness } \\
\text { coefficients for the study } \\
\text { sample in each of the age, } \\
\text { training age, height and weight } \\
\text { ranged between }(-0.04,-0.58) \\
\text { and that these values are been }\end{array}$} & \multicolumn{3}{|c|}{$\begin{array}{l}\text { limited between } \pm 3 \text { and } \\
\text { indicates that vacancy the study } \\
\text { sample from disadvantages of } \\
\text { unmoderated distributions, } \\
\text { which confirms the } \\
\text { homogeneity of the study } \\
\text { sample in those variables. }\end{array}$} \\
\hline
\end{tabular}

Table (2)

The harmonies between the members of the study sample in some physical and skill variables

\begin{tabular}{l|c|c|c|c|c}
\hline \hline $\begin{array}{c}\text { Statistical analyses } \\
\text { Variables }\end{array}$ & $\begin{array}{c}\text { Measurements } \\
\text { unit }\end{array}$ & Mean & Median & $\begin{array}{c}\text { Standard } \\
\text { deviation }\end{array}$ & Skewness \\
\hline $\begin{array}{l}1 . \quad \text { Maximum } \\
\text { strength: } \\
\text { Grip Strength Test }\end{array}$ & $\mathrm{Kg}$ & 27.69 & 27.50 & 3.24 & -0.13 \\
\hline $\begin{array}{l}2 . \quad \text { Muscular } \\
\text { endurance: } \\
\text { Push-up (60)ec) }\end{array}$ & Degree & 46.69 & 47.00 & 3.30 & -0.38 \\
\hline \hline
\end{tabular}

Follow Table (2)

The harmonies between the members of the study sample in some physical and skill variables

\begin{tabular}{l|l|l|l|l}
\hline \hline Statisticalanalyses & Measurements & & Standard & \\
\hline \hline Assiut Journal For Sport Science Arts & & & \\
& &
\end{tabular}




\begin{tabular}{l|c|c|c|c|c}
\hline \hline \multicolumn{1}{c|}{ Variables } & unit & Mean & Median & deviation & Skewness \\
\hline \hline $\begin{array}{l}\text { 3. Power: } \\
\text { Medicine ball throws }\end{array}$ & Miter & 4.36 & 4.22 & 0.57 & 0.40 \\
\hline $\begin{array}{l}4 . \quad \text { Speed: } \\
\text { 30m Sprint Speed Test }\end{array}$ & Second & 4.96 & 4.90 & 0.27 & 0.55 \\
\hline $\begin{array}{l}5 . \quad \text { Agility: } \\
\text { Zig-Zag Test }\end{array}$ & Second & 26.23 & 25.70 & 1.66 & 0.84 \\
\hline $\begin{array}{l}\text { 6. Service stroke: } \\
\text { Target Service Test }\end{array}$ & Degree & 9.81 & 10.00 & 1.68 & 0.24 \\
\hline $\begin{array}{l}7 . \quad \text { Basic strokes: } \\
\text { The general skill } \\
\text { ability test in table } \\
\text { tennis }\end{array}$ & Degree & 57.50 & 55.50 & 8.30 & 0.13 \\
\hline $\begin{array}{l}8 . \\
\text { the general skill ability } \\
\text { of lop stroke in table } \\
\text { tennis }\end{array}$ & Degree & 17.69 & 18.00 & 3.22 & -0.35 \\
\hline \hline
\end{tabular}

It is clear from table (2) that all of the skewness coefficients for the study sample in some physical and skill variables ranged between $(-0.13,-0.84)$ and that these values are been limited between \pm 3 and indicates that vacancy the study sample from disadvantages of unmoderated distributions, which confirms the harmonies of the study sample in those variables.

Table (3)

The equivalence between the two groups of study in some physical and skill variables

\begin{tabular}{l|c|c|c|c|c|c}
\hline \hline \multirow{2}{*}{$\begin{array}{l}\text { Statistical analyses } \\
\text { Variables }\end{array}$} & $\begin{array}{c}\text { Measurements } \\
\text { unit }\end{array}$ & \multicolumn{2}{|c|}{$\begin{array}{c}\text { Control } \\
\text { Group }\end{array}$} & \multicolumn{2}{|c|}{$\begin{array}{c}\text { Experimental } \\
\text { Group }\end{array}$} & \multirow{2}{*}{$t$} \\
\cline { 3 - 6 } & & $\mathrm{MS}$ & $\mathrm{SD}$ & $\mathrm{MS}$ & $\mathrm{SD}$ & \\
\hline \hline $\begin{array}{l}1 . \quad \text { Maximum } \\
\text { strength: } \\
\text { Grip Strength Test }\end{array}$ & $\mathrm{Kg}$ & 27.63 & 3.46 & 27.75 & 3.24 & -.075 \\
\hline $\begin{array}{l}2 . \quad \text { Muscular } \\
\text { endurance: }\end{array}$ & Degree & 45.75 & 3.19 & 47.63 & 3.33 & - \\
Push-up (60)c) & & & & & & 1.148 \\
\hline \hline
\end{tabular}

Follow Table (3)

The equivalence between the two groups of study in some physical and skill variables 


\begin{tabular}{|c|c|c|c|c|c|c|}
\hline \multirow[t]{2}{*}{$\begin{array}{l}\text { Statistical analyses } \\
\text { Variables }\end{array}$} & \multirow[t]{2}{*}{$\begin{array}{c}\text { Measurements } \\
\text { unit }\end{array}$} & \multicolumn{2}{|c|}{$\begin{array}{l}\text { Control } \\
\text { Group }\end{array}$} & \multicolumn{2}{|c|}{$\begin{array}{c}\text { Experimental } \\
\text { Group }\end{array}$} & \multirow[t]{2}{*}{$t$} \\
\hline & & MS & SD & MS & SD & \\
\hline $\begin{array}{l}3 . \quad \text { Power: } \\
\text { Medicine ball } \\
\text { throws }\end{array}$ & Miter & 4.28 & 0.58 & 4.44 & 0.59 & -.553 \\
\hline 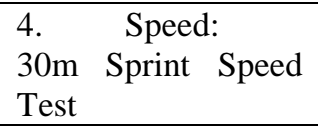 & Second & 5.00 & 0.25 & 4.92 & 0.31 & 0.527 \\
\hline $\begin{array}{l}\text { 5. Agility: } \\
\text { Zig-Zag Test }\end{array}$ & Second & 26.35 & 1.64 & 26.11 & 1.77 & 0.277 \\
\hline $\begin{array}{l}6 . \quad \text { Service } \\
\text { stroke: } \\
\text { Target } \\
\text { Service Test }\end{array}$ & Degree & 9.50 & 1.77 & 10.13 & 1.64 & -.732 \\
\hline $\begin{array}{l}7 . \text { Basic } \\
\text { strokes: } \\
\text { The general skill } \\
\text { ability test in table } \\
\text { tennis }\end{array}$ & Degree & 56.13 & 8.02 & 57.75 & 8.10 & -.403 \\
\hline $\begin{array}{l}8 . \quad \text { Lop strokes } \\
\text { the general skill } \\
\text { ability of lop stroke } \\
\text { in table tennis }\end{array}$ & Degree & 17.63 & 3.20 & 18.00 & 3.70 & -.217 \\
\hline \multicolumn{2}{|c|}{$\begin{array}{l}\text { Table (3) shows the } \\
\text { equivalence between the two } \\
\text { groups of study in some of the } \\
\text { physical and skill variables, } \\
\text { that the value of }(t) \text { calculated } \\
\text { by applying the T test is less } \\
\text { than the value of tabulated }(t) \\
\text { at the level (0.05), which } \\
\text { indicates there is no significant } \\
\text { differences between the two } \\
\text { groups of study in the physical } \\
\text { and skill variables under study, } \\
\text { which means equality of } \\
\text { members of the two groups of } \\
\text { study in these variables before } \\
\text { applying the basic experiment. } \\
\text { - The Pilot Study: }\end{array}$} & \multicolumn{5}{|c|}{$\begin{array}{l}\text { The pilot study was } \\
\text { performed between } 23 \text { / } 1 \text { to } \\
27 \text { / } 1 \text { / } 2015 \text { to implement a } \\
\text { weekly training unit consists of } \\
4 \text { training units contain a } \\
\text { number of tactical drills on } \\
\text { members of the community } \\
\text { study and outside of the basic } \\
\text { sample of the study. That is to } \\
\text { make sure of the extent of } \\
\text { assimilation the members of } \\
\text { that age group for the tactical } \\
\text { performance drills under the } \\
\text { study. } \\
\text { - The Results of Pilot Study: } \\
\text { It was ascertained suitability } \\
\text { the tactical performance drills }\end{array}$} \\
\hline
\end{tabular}


under study and understanding the members of the age group between 12 to 15 years for those drills. It was also standing on the right timing and appropriate period of time to conduct the tactical performance drills for the proposed training program within the training unit.

\section{- Pre-Mesurement:}

The pre- measurement conduct out in between from $29 / 1$ to 31 / 1 / 2015, Where division the study sample into four groups, and conduct a tournament within each group, and ascended the owners of the first and second positions in each group to the upper rounds, and falling the owners of the third and fourth positions to the lowest round, until arrangement the study sample in descending order from the first position to the sixteenth. Then the player with the first position gets 160 points and the player with the sixteenth position gets 5 points only, then were divided the members of the study sample intentionally into two groups, one of them is the control group and they are the owners of the individual positions, and the other is the experimental group and they are the owners of the even positions. Table (2) shows the results of the pre measurement in the dependent variable (matches results).

\section{Table (4)}

The results of the pre-measurement in the variable of matches results between the two groups of study $(n 1=n 2=8)$

\begin{tabular}{l|c|c|c|c|c}
\hline \hline $\begin{array}{l}\text { Statistical } \\
\text { analyses }\end{array}$ & \multicolumn{2}{|c|}{ Control Group } & \multicolumn{2}{c|}{$\begin{array}{c}\text { Experimental } \\
\text { Group }\end{array}$} & \multirow{2}{*}{ Variables } \\
\cline { 2 - 5 } & MS & SD & MS & SD & $t$ \\
\hline \hline Matches Results & 65.00 & 52.37 & 55.00 & 46.13 & 0.405 \\
\hline \hline
\end{tabular}

Table (4) shows the results of pre-measurement in the variable of matches results between the two groups of study, that the value of $(t)$ calculated by applying the $\mathrm{T}$ test is less than the value of tabulated $(t)$ at the level (0.05), which indicates there is no significant differences between the two groups of study in the results of matches, which means equality of members of the two groups of study in the pre measurement.

- Designing the Training

Program: 
After reviewing the researches and references specialized in table tennis, the researcher designed the proposed the training program based on the following basics:

- The duration of the program 12 weeks, from $01 /$ 02 / 2015 to 26 / 04 / 2015.

- $\quad$ The number of training units per week 4 training units, the total number of units of the program 48 units.

- $\quad$ The duration of training unit is between $120-150$ minutes.

- The program contains all of the training components are: 1. The preparatory part (warm-up).

2. The main part (physical preparation - technical preparation - tactical preparation).

3. The concluding part (warm-down).

- The duration of the tactical preparation part was ranging between 40 to 50 minutes.

- The proposed program has been applied to the two groups of study, excluding the allocated part for the tactical preparation for the experimental group, this part was divided into two sections.
The first section has been performing the drills of tactical performance under study, and the second section was performed matches between the players with application the drills of tactical performance that has been trained in the first section through these matches.

- The arrangement of application exercises of tactical performance within the proposed program which applied to the experimental group:

1. Fifth-ball drills.

2. Fourth-ball drills.

3. Third-ball drills.

4. Second-ball drills.

5. First-ball drills.

Each drill of these five kinds of exercises has been applied twice in two consecutive training units.

As for the control group it has been conducting matches between the players during the part which allocated for the tactical preparation in the training units, as is the case in most of the clubs.

\section{- Post-Mesurement:}

The post-measurement has been performed in the dependent variable (matches results) after completion of the application the proposed 
training program, in the period from $28 / 4$ to $30 / 4 / 2015$, where it was conducted a tournament between the members of the two groups of study (experimental - control) as has also been in the pre measurement.
The researcher used the Spss program to get the following statistical transactions:

- Mean.

- Standard deviation.

- Skewness.

- T test.

\section{- Statistical Analyses: \\ $>$ Results and Discussion:}

Table (5): The difference between the pre- and post measurement in the variable of matches results for the members of control group $(n=8)$

\begin{tabular}{l|c|c|c|c|c}
\hline \hline \multirow{2}{*}{$\begin{array}{l}\text { Statistical } \\
\text { analyses }\end{array}$} & \multicolumn{2}{|c|}{ pre measurement } & \multicolumn{2}{|c|}{ post measurement } & \multirow{2}{*}{$\boldsymbol{t}$} \\
\cline { 2 - 5 } $\begin{array}{l}\text { Variables } \\
\text { Matches Results }\end{array}$ & 65.00 & 52.37 & 41.88 & 39.18 & 4.331 \\
\hline \hline
\end{tabular}

Table (5) shows the difference between the pre- and post measurement for the members of the control group in the variable of matches results, showing that the value of $t$ which calculated through the $\mathrm{T}$ test is bigger than the value of tabulated $t$ at the level of (0.05), which indicates that there are significant differences between the pre measurement and the post measurement for the members of the control group in favor of the pre measurement. The researcher is due this result for that the members of control group not owning the tactical thinking which comes through training on tactical performance during the special part of tactical preparation in the training unit. 
Table (6)

The difference between the pre- and post measurement in the variable of matches results for the members of experimental

group $(n=8)$

\begin{tabular}{|c|c|c|c|c|c|}
\hline \multirow{2}{*}{$\begin{array}{l}\text { Statistical } \\
\text { analyses } \\
\text { Variables }\end{array}$} & \multicolumn{2}{|c|}{ pre measurement } & \multicolumn{2}{|c|}{ post measurement } & \multirow[b]{2}{*}{$t$} \\
\hline & MS & SD & MS & SD & \\
\hline Matches Results & 55.00 & 46.13 & 78.13 & 51.40 & -7.083 \\
\hline
\end{tabular}

Table (6) shows the

difference between the pre- and post measuremen for the members of the experimental group in the variable of matches results, showing that the value of $t$ which calculated through the $\mathrm{T}$ test is bigger than the value of tabulated $t$ at the level of (0.05), which indicates that there are significant differences between the pre measurement and the post measurement for members of the experimental group in favor of the post measurement.
The researcher is attributed this result to the positive impact of the proposed training program by the researcher, which has been applied to the experimental group, which has been contained many of the tactical performance drills, which led to possession members of the experimental group for the tactical thinking, which has had a significant impact on the results members of the experimental group in the variable of matches results in the post measurement.

Table (7): Calculate the difference between the members of two groups of study (control - experimental) in the post measurement in the variable of matches results $(n 1=n 2=8)$

\begin{tabular}{l|c|c|c|c|c}
\hline \hline \multirow{2}{*}{$\begin{array}{l}\text { Statistical } \\
\text { analyses }\end{array}$} & \multicolumn{2}{|c|}{ Control group } & \multicolumn{2}{c|}{$\begin{array}{c}\text { Experimental } \\
\text { group }\end{array}$} & \multirow{2}{*}{$t$} \\
\cline { 2 - 5 } & MS & SD & MS & SD & $t$ \\
\hline \hline Matches Results & 41.88 & 39.18 & 78.13 & 51.40 & -1.586 \\
\hline \hline
\end{tabular}

Table (7) shows the results, showing that the value difference between the members of the two groups of study in the post measurement in the variable of matches of $t$ which calculated through the $\mathrm{T}$ test is bigger than the value of tabulated $t$ at the level of (0.05), which indicates that Assiut Journal For Sport Science Arts 
there are significant differences between the members of two groups of study in the post measurement in the variable of matches results in favor of the experimental group. The researcher is attributed this result to the positive impact of the proposed training program by the researcher, which has been applied to the experimental group, which has been contained many of the varieties and graded tactical performance drills, which led to possession members of the experimental group for the tactical thinking, which has had a significant impact on the results members of the experimental group in the variable of matches results in the post measurement.

In this regard see, (David Hewitt 1990) that if two players are equal on a technical level, the possession one of the players to the tactical performance gives him the advantage to win the match, As seen (Jürgen Schicker 2000) the tactical preparation gives the player the ability to the optimal use of his technical, physical, mental and psychological capabilities combined to win the matches, and confirms (Dimosthenis $\mathbf{E}$
2000) on if the player wants to own many of plans of the play it must be mastered this plans, and the only way to master many plans of the play is training on those plans, and thus must contains the training unit many of tactical performance drills. (3:114), $\quad(6: 183)$, (4:72)

And see (Brend Urlich 1987) that possession the player for the tactical thinking enable him to realize the strength and weaknesses of the opponent, and also realize the external surrounding circumstances of the competition, in addition to his ability to achieve the best possible result. $\quad(1: 65,66)$

In this context, pointed (Jürgen Schmecker 2000) that the player does not lose the point until he lose it in his mind first, as he confirms that the table tennis without tactical thinking does not become a table tennis, where he sees that table tennis is a playing chess at speed up to $80 \mathrm{~km} /$ hour, and he confirms too, that the tactical performance not only helps the player to win the matches but also enables him to bring out the best of his technical performance, it is also in case the players are equal in the technical level, the player who 
has the tactical thinking is the closest to win during the matches. $(6: 183)$

\section{Points (Larry Hodges} 2013) to the necessity to possession the table tennis players to the tactical thinking during the matches, and can not possession the players to the tactical thinking once give them some advices before, during and after the matches, but it is necessary the regular and continuing training on the tactical performance, so that it can possession and improvement the tactical thinking for the players, it thus becomes the tactical thinking commonly to the players can be used efficiently and automatically in different situations during the matches, and this is the main objective from the tactical preparation. (7 : 118, 170)

\section{Conclusions:}

1. There are significant differences between the preand post measurement in variable of the matches results for the members of the experimental group in favor of the post measurement.

2. There are significant differences between the two groups of study (control experimental) in the post measurement in variable of the matches results in favor of the experimental group.

3. The proposed training program by the researcher which contains a variety and gradual tactical performance drills produce a positive impact on the match results in the post measurement for the members of the experimental group.

4. The proposed training program led to possession the members of experimental group for the tactical thinking through the continuing training on the variety tactical performance, which has had a positive impact on the matches results for the members of this group in the post measurement in variable of the matches results.

5. The proposed training program showed how important it is to contain the special part of the tactical preparation within the training unit to perform the tactical performance drills, and not satisfaction to perform the matches between the players.

\section{$>\quad$ Recommendations:}

1. Using the proposed training program to develop the tactical performance for the table tennis juniors $12-15$ years. 
2. The need for attention to contain the special part for the tactical preparation within the training unit on the varieties and graded of tactical performance drills, and not satisfaction to perform the matches between the players.

3. Hold further scientific researches and studies with respect to the tactical preparation in table tennis for the different age groups, because there is scarcity of researches and studies conducted in this topic.

\section{References:}

1- Bernd - Ulrich: (1987), Tischtennis praxis, Rowohlt verlag Gross Germany.

2- Bernd - Ulrich: (2011), table tennis, "tips from a world champion", Meger \& Meyer sport, (UK) Ltd.,.

3- David Hewitt: (1990), How to coach table tennis, willow Books, London.

4- Dimothenis E.: (2000), Table tennis from $\mathrm{A}$ to $\mathrm{Z}$, Athens, Greece.

\section{5- Donald Parker, David}

Hewitt: (1993), Table Tennis play the game, blend ford, London.

6- Jürgen Schmicker: (2000), Das Große Buch vom Tischtennis, Jürgen Schimicker, Germany.
7- Larry Hodges: (2013), table tennis tactics for thinkers, Createe Space Independent Publishing Platform. USA.

8- Martin Skloroz: (1980), Table Tennis, EP Publishing Limited, England.

9- Peter Simpson: (1981), How to play Table Tennis, Hamlyn Publishing Group limited, London.

10- Radivoj Hudetz: (2004), Taktik im Tischtennis mit dem Kopf gewinnen, TIBHAR Tibor Haramgozo GmbH, Germany. 11- Richard_Macfee: (2009), Table Tennis, steps to success, Human Kinetics

12- Techeng Wu, Piren $\mathbf{S u}(2010)$, How to Harness the Characteristics of the 11-Point Scoring System for Winning a Table Tennis Match, International Journal of Table Tennis Sciences, No.6 (2010).

13- Wohlgefahrt, Karlheinz: (2004), Tischtennis spezielle Trainingslehre, Brendow \& Sohn verlag GmbH, Moers, Germany.

\section{Assiut Journal For Sport Science Arts}

